\title{
Brosur Apartemen berbasis Android dengan Teknologi Augmented Reality
}

\author{
Estu Sinduningrum, Andhika Julianto \\ Fakultas Teknik Program Studi Informatika \\ Jalan Tanah Merdeka No.6, Kampung Rambutan, Jakarta Timur \\ estu.ningrum@yahoo.co.id, dhikajulian07@gmail.com
}

Diterima: 5 Oktober 2017. Disetujui 17 Oktober 2017. Dipublikasikan November 2017

\begin{abstract}
Abstrak - Smartphone android dapat dimanfaatkan secara maksimal sebagai sarana untuk mempercepat proses mendapatkan informasi dalam bidang pemesanan sebuah apartemen. Oleh karena itu, dibangunlah sebuah aplikasi berbasis android menggunakan teknologi Augmented Reality (AR) untuk membantu karyawan menampilkan bentuk keseluruhan dari suatu apartemen kepada customer. Aplikasi ini dapat menampilkan detail-detail gedung, fasilitas dan kamar. Objek 3D pada aplikasi dikembangkan menggunakan Blender 3D. Aplikasi ini menggunakan marker Natural Feature Tracking (NFT) yang membutuhkan media cetak yang berbentuk gambar, dalam hal ini sebuah brosur. Pengembangan aplikasi menggunakan Unity dan Android S tudio SDK untuk menghasilkan APK yang dapat digunakan pada smartphone android. Pengujian dan implementasi aplikasi ini dilakukan pada PT Louisindo Damai Sejahtera (Apartemen Shinju) dan menghasilkan sinkronisasi gambar 3D dan semua tombol berjalan dengan baik.
\end{abstract}

Kata Kunci: augmented reality, smartphone android, marker, unity.

\section{PENDAHULUAN}

Pada saat ini pemasaran bidang properti, khususnya apartemen yang umum dilakukan adalah menyebarkan informasi melalui media brosur. Namun, hampir sebagian besar masyarakat tidak langsung membaca brosur tersebut, bahkan lebih seringnya brosur tersebut langsung dibuang. Selain itu, brosur juga tidak dapat menampilkan gambar secara detail dan terperinci terkait fasilitas yang terdapat didalam gedung dan ruangan apartemen, karena masih bersifat 2D.

Seiring dengan perkembangan teknologi, keberadaan brosur yang terlalu monoton menyebabkan tidak ada perubahan yang signifikan dalam hal perolehan informasi terkait apartemen.

Apartemen Shinju merupakan salah satu apartemen yang terletak di daerah Cilandak Barat, Jakarta Selatan. Berdasarkan hasil wawancara penulis dengan konsumen Apartemen Shinju, sebagian besar $(79,5 \%)$ mengharapkan perubahan dalam tampilan brosur penawaran apartemen.
Augmented Reality (AR) adalah teknologi yang menggabungkan dunia virtual dan dunia nyata dengan menampilkan objek secara real time sehingga dapat memberikan lebih banyak informasi bagi konsumen. Teknologi AR menyisipkan informasi ke dunia maya dan membentuk informasi tersebut sebagai objek maya. Pengguna di dunia nyata tidak dapat melihat objek maya dengan mata telanjang, sehingga untuk mengidentifikasi objek tersebut diperlukan perantara berupa webcam, komputer, smartphone android, maupun kacamata khusus yang dapat menyisipkan objek maya ke dunia nyata[1].

Berdasarkan uraian di atas, dibuatlah aplikasi untuk menghasilkan sebuah gambar nyata 3D dari bangunan Apartemen Shinju meliputi, gedung, fasilitas, dan interior lainnya secara jelas dan detail berbasis AR. Pada implementasinya, aplikasi ini menggunakan DEVELOPER VUVORIA untuk database marker, teknik Natural Feature Tracking (NFT) untuk pembuatan marker, menggunakan Blender $2.76 \mathrm{~b}$ dan Unity Vuforia untuk membentuk APK.

\section{LANDASAN TEORI}

\section{A. Brosur}

Brosur adalah terbitan tidak berkala yang dapat terdiri dari satu hingga sejumlah kecil halaman, tidak terkait dengan terbitan lain, dan selesai dalam sekali terbit. Halamannya sering dijadikan satu (antar lain dengan strepler, benang, atau kawat), biasanya memiliki sampul, tetapi tidak menggunakan jilid keras. Pamflet yang hanya terdiri dari satu lembar/halaman sering disebut selembaran. Selain itu, brosur yang memuat informasi tentang produk disebut juga dengan katalog[2].

\section{B. Augmented Reality}

AR adalah cara baru dan menyenangkan dimana manusia bisa berinteraksi dengan komputer, karena dapat membawa objek virtual ke lingkungan pengguna, me mberikan pengalaman visualisasi yang alami dan menyenangkan. Sistem AR berbeda 
dengan Virtual Reality (VR), yang sepenuhnya merupakan virtual environtment [1].

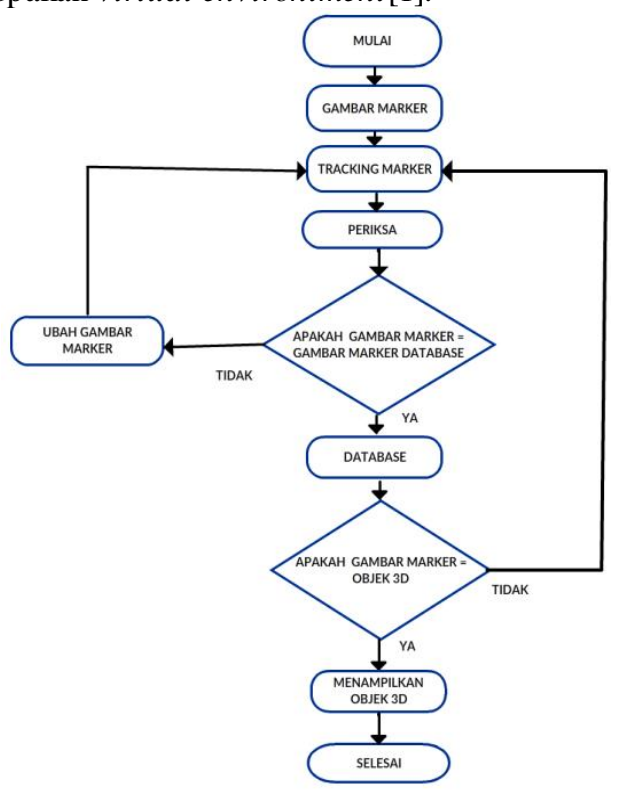

Gambar 1. Cara Kerja Marker[1]

Berdasarkan Gambar 1, langkah awal cara kerja marker menggunakan kamera smartphone untuk mendeteksi gambar marker kemudian akan men-tracking marker dan sistem akan memeriksa marker ke data base, apabila gambar marker tidak sesuai dengan data yang ada dalam data base maka sistem akan memerintahkan untuk mengubah gambar atau mendeteksi ulang gambar marker. Apabila gambar marker sesuai dengan data base pada sistem, maka gambar marker akan menampilkan objek 3D. Hal utama dalam pendeteksian marker adalah marker yang dideteksi harus sesuai dengan marker yang telah disimpan dalam data base.

\section{Modelling $3 D$}

Pemodelan tiga dimensi (3D)/ 3D modelling atau dikenal juga dengan meshing adalah proses pembuatan representasi matematis permukaan tiga dimensi dari suatu objek dengan software tertentu[2]. Produk hasil pemodelan itu disebut model 3D. Model 3D tersebut dapat ditampilkan sebagai citra dua dimensi melalui sebuah proses yang disebut 3D rendering.

Model 3D direpresentasikan dari kumpulan titik dalam 3D, terhubung oleh berbagai macam entitas geometri, seperti segitiga, garis, permukaan lengkung, dan lain sebagainya. Berdasarkan hal tersebut, model 3D dapat dimuat manual (seperti seni memahat), secara algoritma (pemodelan prosedural), atau scanning [3].

Hasil akhir dari citra 3D adalah sekumpulan poligon. Model dengan jumlah poligon yang lebih banyak memerlukan waktu yang lebih lama untuk di-render oleh komputer, karena setiap permukaan memiliki tekstur dan shading tersendiri. Model 3D semakin banyak digunakan, contohnya pada dunia medis, menggunakan model 3D untuk menggambarkan detail organ tubuh, industri perfilman menggunakan karakter atau objek yang dibuat komputer atau Computer Generated Imagery (CGI) yang merupakan model 3D, industri game juga telah menggunakan model 3D, bidang arsitektur menggunakan model 3D untuk mendemonstrasikan rancangan bangunan dengan menggunakan software [3].

\section{Marker}

Marker merupakan sebuah penanda khusus yang memiliki pola tertentu sehingga saat kamera mendeteksi marker, objek 3D dapat ditampilkan[3]. AR saat ini melakukan perkembangan besar-besaran, salah satunya pada bagian marker. Marker pertama adalah marker based tracking. Marker based tracking ini dikembangkan sejak 1980-an dan pada awal 1990-an mulai dikembangkan untuk penggunaan AR. Kemudian markerless, perkembangan terbaru marker ini merupakan salah satu metode AR tanpa menggunakan frame marker sebagai objek yang dideteksi[3].

Dengan adanya markerless AR, maka penggunaan marker sebagai tracking object yang selama ini menghabiskan ruang, akan digantikan dengan gambar atau permukaan apapun yang berisi dengan tulisan, logo, atau gambar sebagai tracking object (objek yang dilacak) agar dapat langsung melibatkan objek yang dilacak tersebut sehingga dapat terlihat hidup dan interaktif, juga tidak lagi mengurangi efisiensi ruang dengan adanya[3].

\section{E. Deteksi Marker}

Proses pelacakan (registrasi marker) adalah beberapa objek yang dapat dilacak dan didaftar oleh QCAR SDK. Dalam proses pelacakan ada beberapa parameter untuk menentukan objek yang akan dilacak[3]. Adapun parameter tersebut adalah nama, ID, status dan posisi yang disimpan dalam state object. Target gambar adalah satu dari banyaknya proses pelacakan. Deteksi sudut atau Corner Detection merupakan pendekatan yang digunakan untuk mengekstraksi beberapa jenis fitur dan menyimpulkan isi dari suatu gambar[3].

\section{F. Unity}

Unity merupakan suatu aplikasi yang digunakan untuk mengembangkan game multi platform yang didesain untuk mudah digunakan[4]. Unity itu bagus dan penuh perpaduan dengan aplikasi yang profesional. Editor pada Unity dibuat dengan user interface yang sederhana. Grafis pada Unity dibuat dengan grafis tingkat tinggi untuk OpenGL dan directX. Unity mendukung semua format file, terutamanya format u mu m seperti semua format dari art applications. Unity cocok dengan 
versi 64-bit dan dapat beroperasi pada Mac OS x dan Windows dan dapat menghasilkan game untuk Mac, Windows, Wii, iPhone, iPad, dan Android[5].

\section{G. Multimedia Development Life Cycle (MDLC) Metode yang digunakan dalam} pengembangan aplikasi ini adalah MDLC yang memiliki 6 tahap yaitu, concept, design, collecting content material, assembly, testing dan distribution[6].

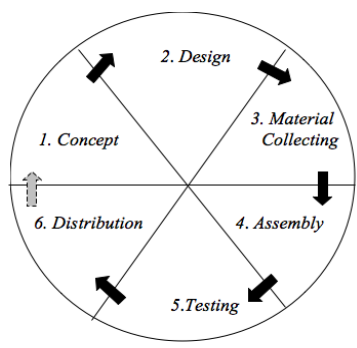

Gambar 2. Alur MDLC [6]

\section{1) Concept}

Tahap concept (konsep) yaitu menentukan tujuan dan siapa pengguna program (identifikasi audience), seperti aplikasi (presentasi, interaktif, dan lain-lain), tujuan aplikasi (informasi, hiburan, pelatihan, dan lain-lain), dan spesifikasi umum. Dasar aturan untuk perancangan juga ditentukan pada tahap ini, seperti ukuran aplikasi, target, dan lain-lain. Tujuan dan pengguna akhir program berpengaruh pada nuansa multimedia sebagai pencerminan dari identitas organisasi yang menginginkan informasi sampai pada pengguna akhir. Karakteristik pengguna termasuk ke mampuan pengguna juga perlu dipertimbangkan karena dapat mempengaruhi pe mbuatan design.

\section{2) Design}

Design (perancangan) adalah membuat spesifikasi secara rinci mengenai arsitektur program, gaya, tampilan dan kebutuhan material / bahan untuk program. Spesifikasi dibuat cukup rinci sehingga pada tahap berikutnya, yaitu material collecting dan assembly tidak diperlukan keputusan baru, tetapi menggunakan apa yang sudah ditentukan pada tahap design. Namun demikian, sering terjadi penambahan bahan atau bagian aplikasi ditambah, dihilangkan, atau diubah pada awal pengerjaan proyek. Tahap ini biasanya menggunakan storyboard untuk menggambarkan deskripsi tiap scene, dengan mencantumkan semua objek multimedia dan tautan ke scene lain dan bagan alir (flowchart) untuk menggambarkan aliran dari satu scene ke scene lain.

\section{3) Material Collecting}

Material Collecting (pengumpulan bahan) adalah tahap pengumpulan bahan yang sesuai dengan kebutuhan yang dikerjakan. Bahan-bahan tersebut, antara lain gambar clip art, foto, animasi, video, audio, dan lain-lain yang dapat diperoleh secara gratis atau dengan pemesanan kepada pihak lain sesuai dengan rancangannya. Tahap ini dapat dikerjakan secara paralel dengan tahap assembly.

\section{4) Assembly}

Tahap pembuatan (assembly) adalah tahap pembuatan semua objek atau bahan multimedia. Pembuatan aplikasi berdasarkan storyboard, bagan alir (flowchart), dan struktur navigasi yang berasal pada tahap design.

\section{5) Testing}

Tahap testing (pengujian) dilaku kan setelah menyelesaikan tahap pembuatan (assembly) dengan menjalankan aplikasi/ program dan dilihat apakah ada kesalahan atau tidak. Tahap pertama pada tahap ini disebut juga sebagai tahap pengujian alpha (alpha test) yang pengujiannya dilakukan oleh pembuat atau lingkungan pembuatnya sendiri. Setelah lolos dari pengujian alpha, pengujian beta yang melibatkan pengguna akhir akan dilakukan.

\section{6) Distribution}

Tahap ini aplikasi akan disimpan dalam suatu media penyimpanan. Tahap ini juga dapat disebut tahap evaluasi untuk pengembangan produk yang sudah jadi supaya menjadi lebih baik. Hasil evaluasi ini dapat digunakan sebagai masukan untuk tahap concept pada produk selanjutnya.

\section{PENERAPAN METODE MDLC}

Berikut adalah tahap-tahap pembuatan aplikasi sesuai dengan metode MDLC.

1) Concept

Tujuan pembuatan aplikasi ini adalah untuk aplikasi untuk memberikan informasi berupa gambar 3D Apartemen Shinju meliputi, gedung, fasilitas dan interior berbasis AR. Pengguna aplikasi ini adalah konsumen dari apartemen. Berdasarkan analisis terhadap kebutuhan aplikasi ini, diperoleh spesifikasi sebagai berikut :

a. Perangkat Keras

Perangkat keras untuk me mbuat aplikasi in i adalah:
1) Prosessor
: Intel Core i3 $1.6 \mathrm{Ghz}$
2) $R A M$
: $4 \mathrm{~GB}$
3) Harddisk
: $500 \mathrm{~GB}$
4) $V G A$ Sedangkan perangkat keras untuk menerapkan/ menggunakan aplikasi ini adalah:
1) Device : Samsung (GT-N5100)
2) $R A M$ $: 2 \mathrm{~GB}$
3) Camera : $8 \mathrm{MP}$.

: Nvidia GeForce with CUDA ${ }^{\text {tm }}$ 

adalah:

Perangkat lunak untuk membuat aplikasi ini

1) Sistem Operasi : Windows 7 Ultimate

2) Aplikasi : Unity, Vuforia, Blender, dan Brosur (Marker)

Perangkat lunak untuk menerapkan/ menggunakan aplikasi ini adalah:

1) Sistem Operasi : Android version 4.4 .2 (Minimal Jellybean)

2) Baseband : V.N5100DXDNG1

2) Design

Berikut adalah diagram use case aplikasi AR Apartemen Shinju:

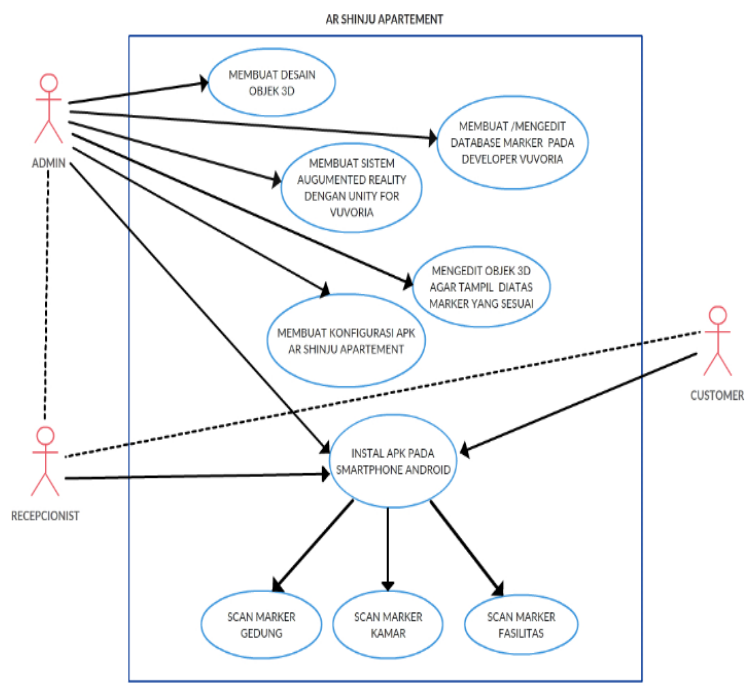

Gambar 3. Use Case Aplikasi

Mengacu pada diagram use case pada Gambar 3, aktor-aktor yang terlibat pada aplikasi in i adalah admin, resepsionis dan customer. Admin dapat membuat desain objek 3D, membuat $\mathrm{AR}$ dengan Unity, mengedit data base AR, mengedit objek 3D, membuat konfigurasi APK Apartemen Shinju.

Resepsionis dan customer memiliki privilege yang sama, setelah menginstal APK pada smartphone, resepsionis atau customer dapat melakukan scan marker gedung, scan marker kamar, dan scan marker fasilitas.

\section{3) Implementation}

Pada tahap implementasi, proses material collecting dan assembly dilaku kan secara bersamaan. Materi yang dikumpulkan berupa gambar atau fotofoto terkait kebutuhan aplikasi Apartemen Shinju. Berikut adalah hasil assembly aplikasi AR Apartemen Shinju:

- Implementasi Antarmuka

Implementasi antarmuka menampilkan hasil implementasi program pada sebuah brosur berbas is
$A R$ berupa tampilan yang dibangun sesuai hasil perancangan.

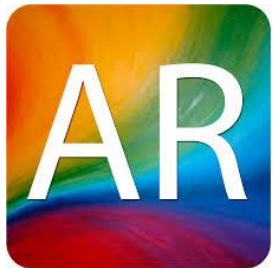

Gambar 4. Tampilan Logo AR Apartemen Shinju

Gambar 5 adalah logo dari aplikasi AR Apartemen Shinju. Pada saat aplikasi AR Apartemen Shinju dijalankan akan terhubung langsung dengan kamera yang ada pada device atau smartphone android, selanjutnya kamera tersebut akan mendeteksi atau men-scan pada sebuah brosur yang sudah dijadikan marker yang dikenali oleh sistem AR Apartemen Shinju.

- Tampilan Scan Marker Pada Brosur

Tampilan scan berisi tampilan ARCamera yang dapat digunakan untuk membaca marker dan memunculkan objek 3D yang nantinya digunakan oleh customer dan resepsionis sebagai salah satu promosi penjualan dan pemesanan sebuah kamar yang bersifat interaktif dan menarik serta dapat mempermudah dalam melihat tampilan gedung, fasilitas dan kamar dengan bentuk yang menarik dan nyata.

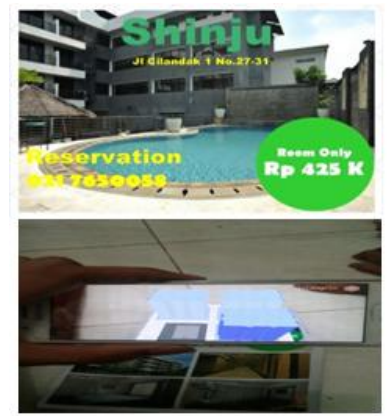

Gambar 5. ARCamera Mengidentifikasi Marker Gedung

Gambar 6 menjelaskan tentang aplikasi AR yang dapat mengenali marker gedung yang terdapat dalam brosur sehingga dapat menampilkan objek 3D berbentuk gedung.

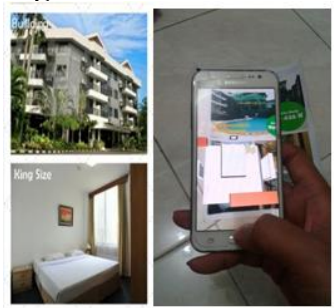

Gambar 6. ARCamera Mengidentifikasi Marker Kamar. 
Gambar 7 menjelaskan tentang aplikasi AR yang dapat mengenali marker kamar yang terdapat dalam brosur sehingga dapat menampilkan objek 3D berbentuk kamar. Gambar 8 menjelaskan tentang aplikasi AR yang dapat mengenali marker fasilitas yang terdapat dalam brosur sehingga dapat mena mpilkan objek 3D berbentuk fasilitas .

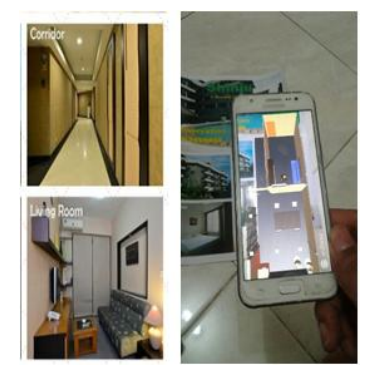

Gambar 7. ARCamera Mengidentifikasi Marker Fasilitas

\section{4) Testing}

Pengujian sistem dilakukan untuk memeriksa apakah setiap komponen atau elemen-elemen di dalam hasil program telah bekerja dan berfungsi dengan yang diharapkan.

Pengujian menggunakan metode black box testing, dengan memberikan input ke sistem dan melihat apakah hasil output yang dihasilkan sudah sesuai dengan apa yang diharapkan atau belum. Hasil dari pengujian terhadap sistem ditampilkan dala m bentuk tabel 1 .

TABEL 1. HASIL PENGUJIAN SISTEM

\begin{tabular}{|c|c|c|c|}
\hline $\begin{array}{l}\text { Butir } \\
\text { Menu }\end{array}$ & Pengujian & Hasil & Keteran gan \\
\hline $\begin{array}{l}\text { Tampilan } \\
\text { Menu Utama } \\
\text { Logo AR } \\
\text { Shinju } \\
\text { Apartemen }\end{array}$ & $\begin{array}{l}\text { User } \\
\text { menjalankan } \\
\text { aplikasi AR } \\
\text { Shinju } \\
\text { Apartemen }\end{array}$ & $\begin{array}{l}\text { Menampilkan } \\
\text { AR kamera } \\
\text { untuk proses } \\
\text { scan marker }\end{array}$ & Berhasil \\
\hline \multirow{3}{*}{$\begin{array}{l}\text { Tampilan } \\
\text { Augmented } \\
\text { Reality } \\
\text { kamera }\end{array}$} & $\begin{array}{l}\text { User } \\
\text { mengarahkan } \\
\text { kamera kearah } \\
\text { marker gedung }\end{array}$ & $\begin{array}{l}\text { Muncul } \\
\text { model 3D } \\
\text { gedung }\end{array}$ & Berhasil \\
\hline & $\begin{array}{l}\text { User } \\
\text { mengarahkan } \\
\text { kamera kearah } \\
\text { marker kamar }\end{array}$ & $\begin{array}{l}\text { Muncul } \\
\text { model 3D } \\
\text { kamar }\end{array}$ & Berhasil \\
\hline & $\begin{array}{l}\text { User } \\
\text { mengarahkan } \\
\text { kamera kearah } \\
\text { marker } \\
\text { fasilitas }\end{array}$ & $\begin{array}{l}\text { Muncul } \\
\text { model 3D } \\
\text { fasilitas }\end{array}$ & Berhasil \\
\hline $\begin{array}{l}\text { Tampilan } \\
\text { Button } \\
\text { Keluar pada } \\
\text { Augmented } \\
\text { reality }\end{array}$ & $\begin{array}{l}\text { User Klik } \\
\text { Button Keluar. }\end{array}$ & $\begin{array}{l}\text { Aplikasi AR } \\
\text { Shinju } \\
\text { Apartemen } \\
\text { akan keluar }\end{array}$ & Berhasil \\
\hline
\end{tabular}

\section{PENUTUP}

\section{A. Kesimpulan}

1. Aplikasi ini dibangun sebagai media informasi yang dapat menjelaskan secara lebih detail kepada customer tentang bentuk keseluruhan dari Apartemen Shinju dalam objek 3D menggunakan teknologi $A R$.

2. Aplikasi AR Apartemen Shinju sudah diimplementasikan di PT. Louisindo Damai Sejahtera (Apartemen Shinju). Pengujian kepada customer dilakukan dengan menggunakan UAT, Berdasarkan hasil perhitungan kuesioner, sebesar $78.853 \%$ customer menyatakan lebih tertarik dalam pemesanan apartemen menggunakan teknologi Augmented Reality ini.

\section{B. Saran}

1. Penambahan bentuk bangunan objek 3D yang lebih variatif dan beragam untuk ditampilkan pada AR Apartemen Shinju.

2. Penambahan beberapa jenis gambar pada brosur Apartemen Shinju agar semua jenis ruangan yang ada di Apartemen Shinju dapat terlihat.

3. Pengembangan aplikasi AR Apartemen Shinju tidak hanya berbasis android tetapi pada semua jenis smartphone yang mempunyai platform lainnya seperti pada iOS dan web.

\section{REFERENSI}

[1] Augmented Reality Menurut Suryawinata , 2010 http://repository.widyat ama.ac.id/xmlui/bitstream/handle/1 23456789/5863/Bab\%202.pdf? sequence $=10$

[2] Perancangan Brosur Interaktif berbasis Augmented Reality http://sinta2.ristekdikti.go.id/index.php?ref=journal\&mod= viewiournal\&journal $=1028 \&$ issue $=\% 20 \mathrm{Vol} \% 204, \% 20$ No $\% 206 \% 20(2015): \% 20$ Jurnal\%20Teknik\%20Elekt ro\%20da n\%20Komputer

[3] Augmented Reality Menurut Ronald T. Azuma, 2008 http://e-journal.uajy.ac.id/5157/4/3T F05511.pdf

[4] Pranata Arya, Baskara. 2015. Mudah Membuat Game Dan Potensi Finansialnya Dengan Unity 3D. Jakarta: PT. Elex Media Komputindo.

[5] Herman, Apa itu Unity ?, "hermantolle.com," e-learning $\begin{array}{lll}\text { class, } & \text { [Online]. Available: }\end{array}$ http://www.hermantolle.com/class/docs/unity-3d-gameengine/. Diakses 2 Maret 2017.

[6] MDLC (Multimedia Development Life Cycle) Menurut Sutopo, $2003 . \quad$ Halaman5. http://ejournal.amikompurwokerto.ac.id/index.php/telemati ka/article/viewFile/246/221 